\title{
ADDITIVE MANUFACTURING IN SMES: EMPIRICAL EVIDENCES FROM ITALY
}

\author{
Giacomo Marzi \\ Lincoln International Business School, \\ University of Lincoln, Lincoln, $U K$ \\ gmarzi@lincoln.ac.uk \\ Lamberto Zollo \\ University of Florence, \\ Department of Sciences for Business \& Economic, Florence, IT \\ lamberto.zollo@unifi.it \\ Andrea Boccardi \\ University of Florence, \\ Department of Sciences for Business \& Economic, Florence, IT \\ andrea.boccardi@unifi.it \\ Cristiano Ciappei \\ University of Florence, \\ Department of Sciences for Business \& Economic, Florence, IT \\ cristiano.ciappei@unifi.it
}

\begin{abstract}
Research on innovative technological methods in SMEs' production processes is progressively receiving attention. However, little is known about the emerging phenomenon of Additive Manufacturing (AM), which may represent a significant strategic lever for fostering a company's competitiveness and performance, especially for SMEs. Our aim is to investigate the effects of AM on SMEs' production process, in order to better understand the relative outcomes of such an innovative technique. We used latent content analysis for empirically analyzing SMEs present in one of the most important Italian gold jewelry districts. Our findings suggest that the AM introduction in a company's production process effectively results in many positive outcomes, such as process innovation, customer satisfaction, costs, revenues, profits, and competitive advantage. Specifically, there is a positive linkage between AM and a company's performance. Hence, such an innovative technique may be interpreted as a viable growth strategy for SMEs. Theoretical and managerial implications are discussed.
\end{abstract}

Keywords: additive manufacturing, 3D printing, 3DP, process innovation, product innovation, new product development, SMEs, competitiveness, case study, Italy.

Giacomo Marzi is a lecturer in Strategy and Entreprise at Lincoln International Business School. His research is mainly focused on innovation management, new product development and bibliometric. He has authored and co-authored a number of papers that appeared in journals such as Scientometrics, Business Process Management Journal and World Review of Entrepreneurship, Management and Sustainable Development. His work has also been presented at conferences such as the Academy of Management and the European Academy of Management. 
Lamberto Zollo is a post-doc candidate in Management and Business Administration at University of Florence. His research interests include strategy, business ethics, social entrepreneurship, and cross-sector social interactions. He carried out research activities at Kent Business School (UK) as a $\mathrm{PhD}$ visiting student. He attended many international conferences of general management and business ethics.

Andrea Boccardi is a post-doc candidate in Management and Business Administration at University of Florence. His research interests focus on entrepreneurship, innovation, business ethics, and social entrepreneurship.

Cristiano Ciappei is a full professor in Strategy at University of Florence. His research interests focus on business ethics, strategy, innovation, business ethics, big data and social entrepreneurship. 


\section{Introduction}

Additive Manufacturing (AM) represents a recent technological innovation that is attracting growing interest from manufacturing firms and is proving to be viable in different sectors. Although AM in manufacturing environments is increasingly gaining attention, pertinent literature has addressed this type of innovation almost exclusively from a technical point of view, and only within an engineering perspective (Lee, 2004; Dimitrov, 2006).

The study of AM as a process innovation in manufacturing firms can help broaden the literature in this area of research, since this type of innovation appears to be less developed than product innovation (Becheikh et al., 2006; Reichstein and Salter, 2006; Taifi et al., 2012, Marzi et al., 2017) and the current literature posits that AM is one of the most disruptive processes of the current decade (Reeves et. Al, 2011; Sealy, 2011; Petrick and Simpson, 2013). Thus, the effects of introducing AM in firms' production processes have not been adequately studied. To fill such a literature gap, the present research aims to explore the impact of AM on manufacturing SMEs' competitiveness and performance. Notably, this study aims to verify whether the introduction of AM can determine the typical effects of process innovations in the following ways: (1) to promote product innovation; (2) to improve productivity; (3) to improve competitiveness (Martinez-Ros, 1999; Reichstein and Salter, 2006; Hall et al., 2009). Regarding practical implications, the goal of this study is to increase the awareness of managers about the importance of such an innovation and its effect on SMEs (Linder et al., 2003).

This article is composed of five sections including this introduction. In the second section, the authors introduce the phenomenon of AM showing how such technology may be configured as a process innovation for SMEs. In the third section, after highlighting the significance of the sample and why it was chosen, the methodology is presented by way of a qualitative analysis of case studies through latent content analysis. The analysis led to the following six conceptual themes: process innovation, cost, value offered to the customer, revenue, profits, and the competitive advantage. The six conceptual themes resulting from this analysis explain the effects of AM on SMEs; the impact of AM on craftsmanship growth and competitiveness in SMEs is particularly emphasized. Consequently, in examining the effects of this technology on these aspects, it is possible to understand the overall effects of AM on SMEs. Finally, the last section highlights the main conclusions along with managerial implications and the limitations of the present work.

\section{AM as an Innovation Process}

\subsection{The Innovation Process}

Management scholars traditionally stress how innovativeness is crucial for firms' performance and survival (Damanpour, 1991; Smith et al., 2005; Knight and Cavusgil, 2004). There is broad recognition that the introduction of innovative products and processes fosters the ability of organizations to enter into or create new markets by satisfying the demand of customers (Smith et al., 2005). This is an essential requirement to sustain a competitive position in an increasingly technologically advanced environment ( $\mathrm{Li}$ et al., 2013). For this purpose, acquiring new information and knowledge is fundamental to the creation of innovative products and services in firms (Katila and Ahuja, 2002; Knudsen and Levinthal, 2007). The innovation process requires the development of new products and services, along with the identification and the exploitation by the management of innovative changes that progressively allow the firm's sustainability in a competitive environment (Katila, 2002; Witt, 2009; Maggitti et al., 2013). As a consequence, it is clear that innovation has an effect on both behavior and organizational relationships, as well as on strategies and firm processes (Li et al., 2013). 
The literature regarding innovation focuses on the identification of possible classifications regarding this concept (Miller and Miller, 2012). The most famous are: (1) the distinction between administrative innovation or technical developments concerning the organizational process involved (Daft , 1978; Kimberly and Evanisco, 1981; Damanpour, 1987); (2) the differentiation between product innovation or process innovation regarding the specific object of innovation (Utterback and Abernathy, 1975); (3) the distinction between incremental innovation and radical innovation, relative to the level of technological advancement imprinted within the organization (Ettlie et al., 1984; Dewar and Dutton, 1986; North and Tucker, 1987).

The second distinction between product and process innovation is considered especially fundamental to the pursuit of competitive advantage, and will be one of the primary focuses of the present research (Hull et al., 1985; Sorli and Stokic, 2011). While product innovation is related to new products and services introduced into the market, usually to meet latent needs of consumers (Ettlie, 1983; Damanpour, 1991), process innovation refers to new elements introduced in the firms' operations and production processes such as new materials, equipment for firms' inputs, information flow, and work tasks (Utterback and Abernathy, 1975; Damanpour, 1991). The latter typology of innovation represents the object of study of the present research.

For the purpose of this study is also important to remark that innovation fosters firms' growth, internationalization, and performance and this effect are both visible in large firms and SMEs (Sapienza et al., 2006). In particular, recent literature has widely focused on innovativeness in SMEs (Ruzzier et al., 2006; Siqueira and Cosh, 2008).

Enhancing innovativeness in SMEs is crucial for the economic development of community and regions (Jones and Tilley, 2003), and it fosters strategic alliances and collaborations between such firms (Kleinknecht and Reijnen, 1992; Narula, 2004). Laursen and Salter (2004) found that innovation is present in SMEs as well as in large-size firms, especially concerning radical modernization. Intriguingly, Lee et al. (2010) stressed how open innovation is essential for SME's development, arguing that "Where large firms focus mainly on R\&D in open innovation efforts, SMEs focus more on commercialization because, while many of them have superiorities in technology for invention, they often lack the capacity in terms of manufacturing facilities, marketing channels, and global contacts to introduce them effectively to the innovation market" (p.291; see also Laursen and Salter, 2006). The incidence of open innovation on SMEs has recently been analyzed by Van de Vrande et al. (2009), who find that small firms are increasingly achieving a noticeable role in modern innovation scenarios. Notably, the authors stress how "innovation in SMEs is hampered by a lack of financial resources, scant opportunities to recruit specialized workers, and small innovation portfolios so that risks associated with innovation cannot be spread. SMEs need to heavily draw on their networks to find missing innovation resources" (p.426). In line with these results, Chang et al. (2011) proposed several assumptions concerning such a topic, pointing out that: (a) the development and improvement of knowledge increases both explorative and exploitative innovative ability of the firm; (b) high levels of dynamism and competitiveness are positively correlated with the SME's innovation; (c) innovation in SMEs represents a partial mediator between the dynamic and competitive environment and the firm's performance (p.1663). It thus emerges that innovativeness is crucial for SME's organizational, technological, and strategic development. However, due to the specific features characterizing SMEs, managers have to be aware of the risks and boundaries linked to applying technological advances in the firms' organizational structure. That is why strategic alliances, knowledge-based investments, and entrepreneurial awareness and motivations about this phenomenon are crucial factors to be assessed.

In general, SMEs have neither access to higher resources to invest in R\&D nor the possibility to invest in human resources devoted to development programs. Hence, innovative activities and informal problem-solving activities are closely linked to the production process (Freel, 2005). SMEs differ from large firms because of the investments made to support innovations. In fact, in large firms, investments in R\&D prevail, while in SMEs the major expenses are the acquisition of new 
machinery, equipment, and facilities to encourage innovation (Evangelista et al., 1997). Finally, it is noted that for SMEs, innovation is a key factor to survival, growth, and development (Acs and Audretsch, 1990). In particular, for small and medium-sized firms, innovation is needed to counter the weaknesses arising from operating in a global context (Hoffman et al., 1998; Ruzzier et al., 2006).

To create value in this globalized environment for SMEs, it is necessary to constantly innovate and exploit new opportunities for maintaining a competitive advantage (Sapienza et al., 2006; Hurmelinna-Laukkanen et al., 2008). In particular, manufacturing SMEs need to continually improve their processes to maintain a competitive advantage in the long term (Lagacé and Bourgault, 2003).

\subsection{Innovation in Manufacturing Firms}

The different typologies of innovation traditionally stressed by literature (Utterback and Abernathy, 1975; Hull et al., 1985) acquire particular significance in the context of the manufacturing industry. Innovation studies show that the two types of innovation described above, namely product and process innovation, are closely linked and interdependent (Martinez-Ros, 1999). Neglecting the initial process may weaken the firms' ability to achieve product innovation, thus compromising the entirety of the firms' advancement (Becheikh et al., 2006). Becheikh (2006) shows that a large part of the literature analyzes only the product innovations; however, only a minor percentage of works focus exclusively on process innovation. Nevertheless, certain studies delve into the characteristics of process innovation and highlight its importance (Martinez-Ros, 1999; Reichstein and Salter, 2006; Raymond and St-Pierre, 2010). Firstly, process innovation increases firms' productivity (Reichstein and Salter, 2006). Second, process innovation achieves competitive advantages mainly through the reduction of production costs (Reichstein and Salter, 2006) and the increasing production flexibility (Lefebvre et al., 1991). Finally, process innovation can promote product innovation (Martinez-Ros, 1999; Hall et al., 2009). The main contributions to process innovations show that investments related to product innovation regard the acquisition of new machinery, equipment and facilities (Hall et al., 2009), while investments in R\&D are mostly related to product innovations. Analyzing Italian manufacturing firms, Evangelista et al. (1997) show the existence of two innovation models: the pattern of large firms founded on R\&D investment and innovation models of SMEs characterized by informal modernizations.

Innovation in manufacturing firms assumes special features and is different from innovation in service firms (Becheikh et al., 2006). Numerous contributions have focused on studying innovation in the manufacturing sector (Evangelista et al., 1997; Freel, 2000; Becheikh et al., 2006; Reichstein and Salter, 2006; Hall et al., 2009; Raymond and St - Pierre, 2010; Terziovski, 2010). Notably, Sirilli and Evangelista (1998) compare the characteristics of process innovation in manufacturing and service firms noting that, in most of the analyzed firms, product innovation is considered equally significant - a claim supported by Linder et al. (2003), who found significant strategic implications for integrating innovation processes in firms' competitive advantage. Moreover, another important difference is related to the cost of innovation that in manufacturing firms is about three times more than in service firms (Sirilli and Evangelista, 1998). Further, a longitudinal analysis (Becheikh et al. 2006) of literature regarding innovation in manufacturing firms demonstrates that research projects in this area are mainly dedicated to those concerning product innovation. The literature review made by Becheikh et al. (2006) on innovation in manufacturing firms show that most scholars focus only on product innovations. However, only a slight percentage of work focuses exclusively on process innovation as a result of scarce scholarly interest (Becheikh et al., 2006; Reichstein and Salter, 2006). This type of innovation is often seen as an innovative activity of lesser importance compared 
to product innovation (Rosenberg, 1982). Moreover, managers give less consideration to process innovation compared to product innovation (Linder et al., 2003).

For the purpose of the present study, AM manufacturing seems to offer a great way for SMEs' growth and competitiveness (Mellor et. al., 2014) by offering a new and more flexible technology without substantial investments. However, these considerations are not adequately studied due to the novelty represented by this type of innovation. For this reason, an initial exploratory study is needed to shed light on this breakthrough innovation for not only manufacturing SMEs, but also for manufacturing firms in general.

\subsection{AM: Prototyping and Production}

$\mathrm{AM}$ as a technological innovation is increasingly becoming ground-breaking in many industrial sectors, thus acquiring more of a strategic function for improving competitiveness in both large firms and SMEs (Caputo et al., 2016; Kannattukunnel, 2016). Notably, the introduction of AM can be configured as a radical process innovation. Such innovation is done with new machinery, namely $3 \mathrm{D}$ printers, which may be used in prototyping or directly in production for the production of semifinished or intermediate artifacts, and for the production of finished products.

To have an idea about the exponential growth of AM, Forbes (Columbus, 2015) estimates a growth of the AM market in a range from $\$ 7$ billion by 2020 , on 18 percent CAGR to bull market scenarios as high as $\$ 21.3$ billion by 2020 , at 34 percent CAGR. In particular, the worldwide AM printing industry is now expected to grow from $\$ 3.07 \mathrm{~B}$ in revenue in 2013 to $\$ 12.8 \mathrm{~B}$ by 2018 , and exceed $\$ 21 \mathrm{~B}$ in worldwide revenue by 2020 with rapid prototyping $(24.5 \%)$, new product development $(16.1 \%)$ and product innovation $(11.1 \%)$ are the three most common reasons why firms are adopting AM.

Under a technological viewpoint, there are three basic methods by which you can print an object in 3D (Dimitrov, 2006): the Stereo Lithography method (SLA), the 3D-Plotting method, and the Drop on Demand System method (DOD). The first method is based on the polymerization of liquid resin by laser. In this case, the laser creates the entire object from top-to-bottom through material stratification. Once the object is completed it will be extracted and put into an ultraviolet oven to harden the material and make it usable for further work or production.

The 3D-Plotting method, alternatively, is comparable to the operation of an inkjet printer with the only difference being that the main material with which the machine works is a thermoplastic polymer that is solidified on the various layers. In this particular case, the machine is positioned in the working area by depositing a first layer of plastic material. It then begins to move in all three directions to form the $3 \mathrm{D}$ item. In this case, the item from the machine work is finished and immediately ready to be used or colored. Finally, the DOD method is similar to the 3D-Plotting system with the only difference being that the machine works simultaneously on all three Cartesian axes, considerably decreasing the time taken to mold a 3D piece.

It should be noted that the 3D molding phase is preceded by the design of the object using a 3D CAD modeling system based on a physical replication that allows users to touch what is already virtually designed via software (Lee, 2004). Each of these three methods has specific characteristics and different applications: the SLA method is better for the production of prototypes or objects en masse as it allows a higher working speed and the ability to create a series of objects in a single working session. The other two methods are optimal for production requiring high precision or to create very complex shapes, with bends and corners which can hardly be developed through fusion, as in the SLA process.

The first applications of AM in SMEs included the prototype stage, but in recent years, this technology has also been used in the production phase (Mellor et. al., 2014). Currently, the making of finished products through 3D printers is the real frontier for future development of this technology. Examples of objects produced through AM have some pioneering embodiments in the 
biomedical field where, for example, it is possible to create dental prosthesis-ready grafts on the subject (Zollo et al., 2015).

In this area, the AM process has given several benefits: reduced production time of prosthesis development, a significant increase in the accuracy of reproduction of the dental arch and, finally, a significant increase in the level of customization (Katstra, 2004). In general, it seems that the use of $\mathrm{AM}$ in the process of product development reduces costs, increases the speed of development, positively influences the time to market, and fosters a high degree of product customization. Moreover, the AM phenomenon is particularly relevant for SMEs because the introduction of such technology determines more structured and radical innovation than might be pursued in larger companies, where this innovation would have less impact in the production process.

\section{Research Methodology}

In this research, the authors wish to study the introduction of $A M$ as a process innovation in manufacturing firms with the aim of understanding the effects of this innovation on competitiveness. By studying the effects of a particular process innovation, this research expands the literature on this phenomenon by showing that is an important challenge for SMEs' growth and competitiveness (Becheikh et al., 2006; Reichstein and Salter, 2006). In fact, several empirical studies remark the connection between innovation, competitiveness, and growth for SMEs. In particular, regarding the cooperation networks and innovation (Zeng et al., 2010), the link between innovation and exports for SMEs' growth (Golovko and Valentini, 2011), open innovation and competitive performance (Parida et al., 2012) and financial orientation to improve innovation (Tajeddini, 2016).

Moreover, the authors of this paper want to raise awareness among entrepreneurs and managers about the importance of process innovations (Linder et al., 2003) and its effect on SMEs. Thus, this study aims to explore if AM can determine the typical effects of process innovations and if it can be a viable path to growth and competitiveness for SMEs.

In particular, this study wants to explore if AM:

- Promotes product innovation (Martinez - Ros, 1999; Hall et al., 2009).

- Improves productivity and competitiveness (Reichstein and Salter, 2006).

- Improves SMEs growth chances (Love and Roper, 2015).

\subsection{Sample}

To study the effects of AM, the authors chose the jewelry industry because, in this context, AM is widespread and it is consolidated with the peculiarity that is used not only for prototyping but also in the production phase. The jewelry production process requires the production of prototypes, models and semi-finished products that can be made in an advantageous manner with the use of AM technologies and 3D printers in particular.

Within the jewelry industry, this paper analyzes the district of Arezzo because the introduction of AM began in the 2000s and is intensely developing. The firms of Arezzo were the first gold firms to successfully introduce this innovation, and today the use of AM is critical to their competitiveness. The use of AM is a consolidated phenomenon in the sample today and justifies the reason underlying the choice in attempting to understand the economic effects and management insights. In the Arezzo district, the processing of precious metals has been developed on an industrial scale mainly in the nineteen-seventies and eighties. In detail, the system is composed of approximately $70 \%$ of firms dedicated exclusively to jewelry, $24 \%$ exclusively to silverware, while the remaining $6 \%$ equally share turnover in the two sectors. Data are provided by Italian National Statistical Institute (ISTAT) and elaborated by the authors. The turnover of the entire gold jewelry industry and processing of 
precious stones (NACE code 36.2) is around 1,055 million euro (ISTAT data for 2015) representing - along with fashion and nautical - one of the three most important Italian industries in light manufacturing.

The last census in 2014 found 2,045 active firms in Arezzo with a total of 8,903 employees. Although this sector has been affected by the economic downturn, production levels remained satisfactory thanks to the improvement in exports that in 2015 increased again after the exploits of 2013 and a decrease in 2014. Specifically, in the second quarter of 2015, exports increased by $7 \%$ after a year of contraction (ISTAT data for 2013, 2014 and 2015).

Regarding the sample, eight gold jewelry companies from Arezzo that have introduced AM in the production process and use such technology in-house without outsourcing - as other companies in the sector have - were chosen for this research. To select the sample, the authors carried out an initial exploratory analysis during the trade fair "Arezzo Gold 2015", allowing one to define a heterogeneous sample that was representative of the district. Afterward, the exploratory scanning and the consequent data collection and analysis during "Arezzo Gold 2016" fair was completely updated. The eight firms chosen have demonstrated a consolidated use of AM in the production process, the knowledge of the effects on the performance, and the ability to collaborate. The representativeness of the sample is ensured by the heterogeneity of companies regarding turnover, the number of employees, the year when AM was first introduced, family control or presence of outside managers, and type of products. The firms in the sample were defined by the Greek alphabet - alpha, beta, gamma, delta, epsilon, zeta, eta, theta - to ensure the firms' anonymity. Table 1 summarizes the firms' sample.

\begin{tabular}{|c|c|c|c|}
\hline Firms & Yearly Revenues (2015) & N. Employee & Additive Manufacturing Introduction \\
\hline Alpha & $€ 5.250 .189$ & 18 & 2003 \\
\hline Beta & $€ 3.241 .432$ & 31 & 2003 \\
\hline Gamma & $€ 12.308 .621$ & 40 & 2004 \\
\hline Delta & $€ 33.011 .427$ & 86 & 2006 \\
\hline Epsilon & $€ 3.546 .245$ & 12 & 2007 \\
\hline Zeta & $€ 24.765 .027$ & 56 & 2008 \\
\hline Eta & $€ 4.325 .893$ & 29 & 2008 \\
\hline Theta & $€ 11.746 .324$ & 33 & 2009 \\
\hline
\end{tabular}

Table 1 - Sample detailed description

\subsection{Methodology}

The purpose of this study has been pursued with a qualitative methodology supported by a multivariate case study of eight firms that use AM in the gold jewelry industry of Arezzo district. The multivariate case study has been conducted under the guidelines proposed by leading literature (Yin, 2004; Pratt, 2009). This methodological choice rested on the general agreement that qualitative research seeks to answer the "how" and "why" questions, and that the case study method is a useful way of doing so (Eisenhardt, 1989, Yin, 2004).

In this study, the authors have chosen interviews as the method of data collection and latent content analysis as the method of analysis (Mayan, 2009, Berg, 2012).

The researchers employed the three steps of data collection procedures as established by Yin (2004): interviews, documentation, and observation. Also, Woodside and Wilson (2003) agree that case study research should entail multiple approaches to data gathering and through which the in-depth interviews are a fundamental qualitative method performed through open-ended or focused interviews. The researchers opted for a semi-structured, open-ended approach because the variables involved were not clear in the referring literature (Yin, 2004).

The data relating to the phenomenon have always been linked to conceptual subjects that the researchers wanted to reexamine in the light of the new results. The qualitative analysis involved the constant comparison between theoretical concepts and observed phenomena, trying to identify concrete examples relevant to the theoretical level in the data collected (Anderson et al., 2010). 
From a practical viewpoint, after identifying the sample, the researchers conducted semi-structured interviews with top management (Richards and Morse, 2007). According to Richards and Morse (2007), semi-structured interviews are suitable when the authors have a general idea of the phenomenon and can ask questions about the topic but are not able to predict responses (Richards and Morse, 2007; Mayan, 2009). The protocol required scheduled interviews with open-ended questions about the overall effect made by AM and the impact of AM on firms' competitiveness. The subsequent latent content analysis (Mayan, 2009; Berg, 2012) has allowed the identification of conceptual themes that represent particular aspects which, according to the top management, explains the impact of AM on performance.

Data collection was done through personal interviews with a representative of each examined firm. At least two interviews were carried out with owners or managers of each firm for a total of 16 interviews. Table 2 summarizes the interviewed subjects.

\begin{tabular}{|c|c|c|c|c|c|}
\hline$\#$ & Genre & Age & Position & Interview Duration (minutes) & Interview Date \\
\hline 1 & $\mathrm{M}$ & 64 & Owner & 118 & 19 September 2015 \\
\hline 2 & $\mathrm{M}$ & 65 & Owner & 92 & 20 September 2015 \\
\hline 3 & $\mathrm{M}$ & 51 & Owner & 47 & 20 September 2015 \\
\hline 4 & $\mathrm{M}$ & 48 & Manager & 81 & 27 September 2015 \\
\hline 5 & $\mathrm{~F}$ & 48 & Manager & 73 & 27 September 2015 \\
\hline 6 & $\mathrm{M}$ & 52 & Owner & 44 & 9 October 2015 \\
\hline 7 & $\mathrm{M}$ & 46 & Manager & 72 & 9 October 2015 \\
\hline 8 & $\mathrm{M}$ & 55 & Manager & 39 & 9 October 2015 \\
\hline 9 & $\mathrm{~F}$ & 67 & Owner & 45 & 12 October 2015 \\
\hline 10 & $\mathrm{M}$ & 38 & Owner & 111 & 09 May 2016 \\
\hline 11 & $\mathrm{M}$ & 31 & Owner & 54 & 09 May 2016 \\
\hline 12 & $\mathrm{~F}$ & 29 & Manager & 62 & 13 May 2016 \\
\hline 13 & $\mathrm{M}$ & 26 & Manager & 57 & 17 May 2016 \\
\hline 14 & $\mathrm{M}$ & 29 & Manager & 68 & 17 May 2016 \\
\hline 15 & $\mathrm{M}$ & 65 & Owner & 55 & 21 May 2016 \\
\hline 16 & $\mathrm{~F}$ & 41 & Manager & 103 & 21 May 2016 \\
\hline \multicolumn{4}{|c|}{ Total Time } & \multicolumn{2}{|c|}{1121 Minutes } \\
\hline
\end{tabular}

Table 2 - Detailed information about interviewed subjects

Although the interview protocols have been modified and adapted during the process of data collection, the researchers used a set of stable applications that can be summarized and classified in the following topics (for a detailed the interview plot, please see Table 6 in appendix):

a) the economic-financial and strategic reasons that led top management to introduce AM in the production process;

b) the effects of this process innovation on employees, production process, product, costs, revenues, and profits;

c) the evolution of the relationships with corporate stakeholders, with particular focus on the customer;

d) the main consequences of this innovation on economic performance and on the competitive advantage.

In addition to the interviews, the researchers also made six on-site observations guided by managers or owners in order to better understand the phenomena.

Table 3 summarizes the on-site observations: 


\begin{tabular}{|l|l|c|c|}
\hline \multicolumn{1}{|c|}{ Firm } & \multicolumn{1}{c|}{ Area } & Day & Duration (Minutes) \\
\hline Alpha & Production & 20 September 2015 & 62 \\
\hline Beta & Production & 21 September 2015 & 33 \\
\hline Delta & CAD Design & 27 September 2015 & 30 \\
\hline Epsilon & Production & 09 October 2015 & 45 \\
\hline Zeta & Production & 09 May 2016 & 77 \\
\hline Theta & CAD Design & 13 May 2016 & 32 \\
\hline \multicolumn{3}{|c|}{ Total } & $\mathbf{2 7 9}$ \\
\hline
\end{tabular}

Table 3 - Detailed description of on-site observation

Subsequently, the data collected through interviews were analyzed by the method of latent content analysis (Mayan, 2009; Berg, 2012). This is the process of identifying, coding and categorizing the primary topics in the data (Spiggle 1994; Thompson 1997; Mayan, 2009; Berg, 2012). It aims to identify the most important topics within the data to classify it into codes, categories, and themes (Mayan, 2009). Through this process of coding, the analysis highlights the most important themes connected to specific research questions. Consequently, the purpose of latent content analysis is to understand the symbolism underlying the physical data (Berg, 2012). Alternatively, manifest content analysis aims to count specific words used or ideas expressed to generate statistics on the content of the data (Mayan, 2009).

In this study, through latent content analysis, the authors examined the content of the interviews to identify themes that would explain the effects of AM on the competitiveness and performance of the firms. To realize this interpretative process, four steps were followed: coding, categorizing, thematizing, and integrating (Mayan, 2009). The entire process of selection and coding was done manually without the aid of any software.

The process of content analysis began with the analysis of all data collected through interviews, eliminating what has been deemed non-relevant and putting together what was significant (Eisenhardt, 1989).

The first step was to code the data to identify units of meaning connected to the effects of AM within the data set (Mayan, 2009). This phase of coding analysis generated fifty issues that were named 'codes.' Thanks to the support information derived from the Internet, newspapers, magazines, and reports of companies, each of the authors began axial coding to make the group analysis. The results of this second phase of content analysis have been shared with the work team and compared to the differences and concerns raised during the analysis. At this stage, the authors followed the protocol described by Finch (2002), and applied to management research by Anderson et al. (2010).

After this second phase, the conceptual subjects that emerged were reduced to thirty categories. In this phase, the codes were combined and conducted by similarities and affinity of meaning within the same category (Spiggle, 1994). The third phase of analysis identified six themes that represent the main conceptual aspects used by respondents to explain the effects of AM on business competitiveness. These themes tie the categories together, and they were identified with a process of abstraction (Spiggle, 1994; Mayan, 2009). In the last step, namely integrating, the different themes were correlated with each other to form the conclusion and to build the big picture (Spiggle, 1994; Mayan, 2009). This was the real process of theorizing.

\section{Results and discussion}

In this section, the authors present the results of the latent content analysis (see Table 4) with the thirty categories identified in the interviews and associated with the following six conceptual themes: process innovation, cost, value offered to the customer, revenues, profits, competitive advantage. These conceptual themes are the main aspects that respondents have cited to explain the effects of AM during the interviews. 


\begin{tabular}{|l|c|}
\hline $\begin{array}{l}\text { Phase of the production process: prototyping or production } \\
\text { Production of semi-finished or finished product } \\
\text { Impact of innovation on the production process } \\
\text { Determinants of innovation } \\
\text { Use of a new machine }\end{array}$ & $\begin{array}{c}\text { Process } \\
\text { Innovation }\end{array}$ \\
\hline $\begin{array}{l}\text { Amount of the investment in 3D Printer } \\
\text { Incidence of depreciation } \\
\text { Effect on the total costs } \\
\text { Impact on labour costs } \\
\text { Raw materials } \\
\text { Costs for maintenance } \\
\text { Productivity }\end{array}$ & Cost \\
\hline $\begin{array}{l}\text { Product innovation } \\
\text { Quality of products } \\
\text { Time to market } \\
\text { Customization } \\
\text { Customer Service }\end{array}$ & \\
\hline $\begin{array}{l}\text { Effect on total revenue } \\
\text { Effect on the quantities sold } \\
\text { Willingness to pay customers }\end{array}$ & Value Offered \\
Sales prices & \\
Access to new market segments & \\
\hline $\begin{array}{l}\text { Total impact on profits } \\
\text { Improvement of profits } \\
\text { Causes of changes in profits } \\
\text { Value added between the difference in willingness to pay and cost }\end{array}$ & Revenues \\
\hline $\begin{array}{l}\text { Competitive strategy } \\
\text { Innovation imitation } \\
\text { Craftsmanship } \\
\text { Competition with developing countries }\end{array}$ & \\
\hline
\end{tabular}

Table 4 - Latent content analysis analytical results

The six conceptual themes are illustrated graphically (see Figure 1) by the following conceptual scheme that illustrates how these affect the companies' competitiveness. Every circle represents one of the emerged themes and the dashed line represents the whole effect of competitive advantage theme. 


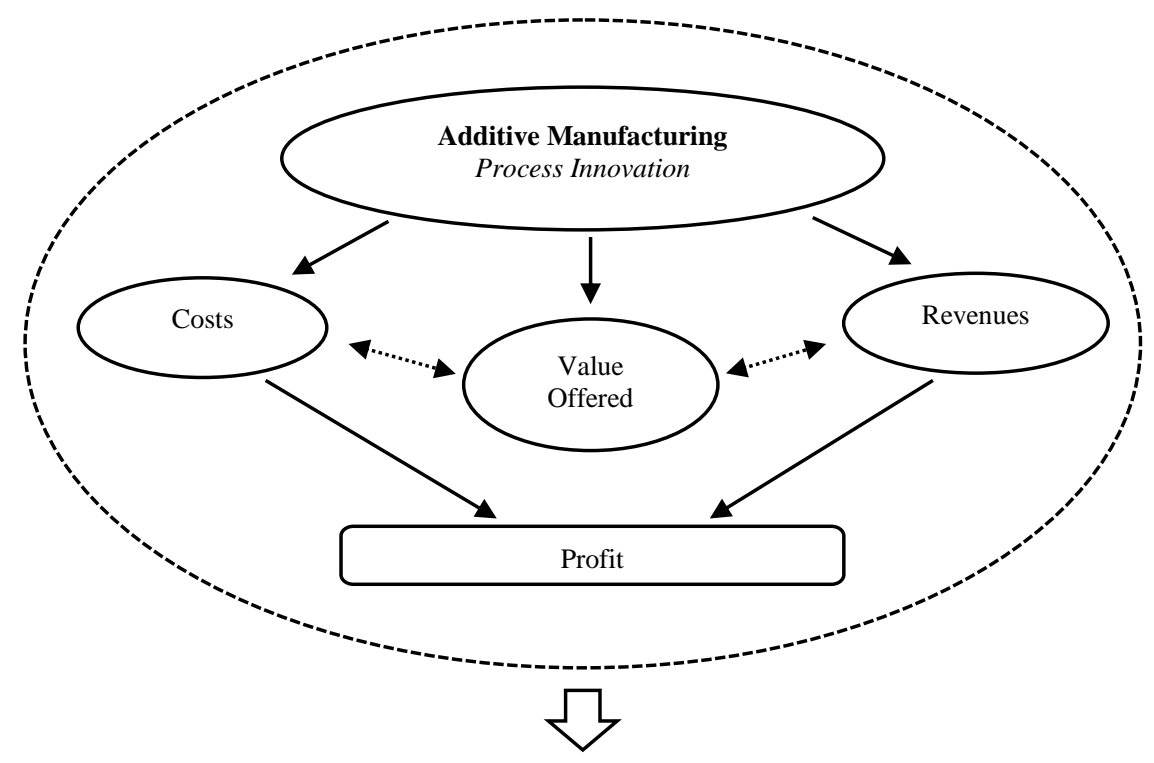

INCREASING IN COMPETITVE ADVANTAGE

Figure 1 - Conceptualization of the emerging themes from latent content analysis

As anticipated, the six conceptual themes resulting from the content analysis are the main features used by respondents to explain the effects of AM on business competitiveness. In other words, the six conceptual themes are the main aspects that are influenced by this technology.

Consequently, by examining the impact of AM on these elements, it is possible to understand the overall effects of this innovation on competitiveness (Mayan, 2009). The primary empirical evidence resulting from interviews, concerning the impact of AM on the six conceptual themes arising from latent content analysis is described below.

\subsection{AM as a Process Innovation}

The first conceptual theme refers to process innovation. The case studies analyzed during the research have shown that AM has significantly increased process innovation in the gold industry.

As Alpha's manager claim: "I was the first to introduce the $3 D$ printing in the gold sector. This sector was the first in which the manufacturing has spread the use of $3 D$ printing at the industrial level, with the peculiarity that in our industry we transformed a machine from prototyping in a machine for the production. After a first phase in which the $3 D$ Printing was used in prototyping, now it is used directly in the production to achieve the molds, from which will be born the jewel".

In the sector under analysis, AM may be qualified as a process innovation. That type of production could previously only be carried out through a long process of manual work done by highly skilled craftsmen. Consequently, one set of empirical evidence is that AM in the gold jewelry firms is used not only in the prototype stage but also in the production phase. The first stage of the production process is accomplished through AM, in which the semi-finished products are created to realize the final output - specifically, the jewels.

Moreover, the cases carried out in the field show that most of the companies internalize this innovation. The analyzed interviews showed that one reason companies push to internalize this technology is the need for absolute control over 3D printers in order to hide information from competitors on the production's progress. Thus, the analyzed firms are internally equipped with this technology, spending resources in the purchase of 3D printers. 
Also, two of the respondents claim that the use of AM for the production of semi-finished products will be overcome by the direct creation "of the jewel through powder sintering metal," as can be perceived from the words of Delta's manager.

Insight 1: AM significantly increased process innovation

\subsection{Effect on Costs}

Regarding the cost effects, case studies have shown that gold jewelry companies that use AM do not have a substantial reduction in costs, while there is "a slight increase caused by the amortization, the costs of maintenance, the costs of training the staff and especially the costs of raw materials," as evidenced by the words of Gamma's manager.

Important evidences concerning the cost regard the change in companies' structure. In fact, there is a high impact on 3D printers' cost amortization of about two years that stimulate the continuous innovation of products and speed up the production cycle. Besides, 3D printers' maintenance costs are significant. Moreover, costs are increased due to necessary personnel training needed to use the new technology. Finally, the cases show that the most critical aspect concerning cost effect is represented by raw material costs as firms are obliged by contract to buy the raw materials for the printer from the 3D printer suppliers.

In fact, Gamma owner remarks: "when I purchased the 3D printer is as if I had married a second time, because we are obliged to buy the resins by those who sold us the 3D printer". These suppliers have high bargaining power due to the high concentration of the AM producer industry.

Insight 2: AM increases production cost due to significant acquisition, maintenance, and personnel

\subsection{Effects on Value Offered to Costumers} expenditures.

The examined cases show that AM promotes advantages related to customer service. First, it encourages product innovation, in line with what the literature says about the process innovations (Martinez-Ros, 1999; Hall et al., 2009). In fact, AM allows firms to create new products, perceived by customers as the finest regarding aesthetics and quality. More specifically, one can talk about innovation that facilitates the process of creating new products without being born for this purpose alone. After the introduction of AM, the analyzed firms in the sample can create objects with complex geometries that were previously impossible to do by hand. It allowed firms to offer new products with greater value, enticing customers to pay higher prices. As Eta's manager pointed out: "The 3D printing has enabled us to create products with the forms that before the introduction of this system of processing were physically impossible to implement, allowing to expand the range of products offered and surprise our regular customers".

The case studies have shown that the primary purpose of the introduction of AM within companies will evolve in the creation of new products. In general, it can be said that the technology in question appears as a process innovation that enables companies to create new products in line with the literature mentioned above (Reichstein and Salter, 2006; Hall et al., 2009).

This evolutionary step, as shown in the following paragraphs, weighs heavily on the opportunities for growth and development of SMEs (Hall and Mairesse, 2009). It is highlighted by Gamma who remark: "Thanks to this processing method the quality of our products has improved exponentially, we can sell at a higher price items with best quality standards."

Thus, AM allows access to new markets and segments, while competition is no longer based only on cost but also on the design and complexity of sold items.

Insight 3: AM encourages product innovation that evolves into new product development. 


\subsection{Effects on Revenues}

Concerning revenues, the case studies show that AM has affected revenues of the firms in two ways. Firstly, revenues increased thanks to higher sale prices connected to the greater value offered to the customer. In fact, customers are willing to pay a higher price for better physical characteristics or new products. Concerning the relationship between price and items sold, AM has affected mainly the former. As stated in the words of the manager from company Zeta, "revenue increased primarily due to higher price sales, made possible by the improvement of product quality." It should also be noted that AM allows the industrial production of small batches as evidenced by the words of the owner of the company Zeta, "the amount was not increased, and also, 3D printers have industrialized the production of small batches."

Secondly, the creation of new products has allowed access to new market segments according to the managers' opinion. In particular, AM made firms more competitive under the cost side by producing handcrafted items en masse. The development of AM has allowed firms in the sample to produce highly refined items at reasonable prices. It allows firms to enter into a mass-market with products which, before the introduction AM, were reserved only to high-end markets due to their high selling prices.

This observed second effect is particularly interesting for SMEs as it allows them to expand their competitiveness even under the cost side, without decreasing their products' quality and craftsmanship.

\subsection{Effects on Profits}

Insight 4: AM affects revenues thanks to a greater willingness to pay by customers.

Regarding the impact of AM in profitability, the case studies show a positive impact. This is possible due to higher revenues in the face of a substantial stability of production costs. In fact, Theta claimed: "profits have improved thanks to higher revenues, compared with a substantial stability of costs".

The analysis of the aforementioned conceptual themes allows us to affirmatively respond to our research question, pointing out that AM improves the competitiveness of SMEs. In fact, the product innovations allowed by AM result in a better value offered to customers, an increase in the willingness to pay, and greater access into new market segments, resulting in an improvement in the revenue stream as noted by Gamma's manager: "the main cause of the profit improvement has been the increase in sales prices"

The positive impact on competitiveness made by AM introduction is in agreement with the literature findings regarding process innovation (Reichstein and Salter, 2006). It should be noted that while the literature on process innovation attributes the improved competitiveness on cost reduction (Becheikh et al., 2006), the introduction of AM primarily produces revenues. Hence, the effect on profits is a direct outcome of an increase in revenues.

Insights 5: AM positively impacts profits thanks to the possibility of access to new markets and segments.

\subsection{Effects on Competitive Advantage}

The sum of the aforementioned results converges in a better competitive advantage as shown in Figure 1 as a cause of AM introduction in manufacturing SMEs. The case studies have shown that $\mathrm{AM}$ is a driver of competitive advantage but not a sufficient factor for such advantage, as this innovation needs to be combined with other production technologies and entrepreneurial skills. As Beta's owner remarks: "The use of $3 D$ printing is fundamental to face with our competitor. Not only the technology can resolve a strategic affair that is composed also by design, customer relation and international geopolitics situation. However, without the use of $3 D$ printing, our company would be failed five years ago".

As the managers involved in the study stated, AM can be easily reproduced by other competitors in the Arezzo district, which creates benefits especially for the first-mover inside that industry. 
However, once AM has been introduced by the first-mover, it has become a required factor for survival. Nevertheless, the "forced" large-scale adoption of AM within the district pushes the firms inside it to improve the quality of its products. The final result of this competition shows their outcomes in a better aggregate of competitive advantages for all the firms in the district. In fact, as Beta noted: "The introduction of $3 D$ printing by other companies of the district does not cause an adverse effect on our competitiveness nor on profits, but rather improves the reputation and image of the district by promoting our ability to create unique products and makes it more competitive aggregate level."

Finally, the main competitive advantage created by AM regards the competition within developing countries. As the Gamma manager remarks, this technology allows SMEs not to fear the threat from developing countries. As Gamma's manager pointed out, "[...] in any case it is preferable to compete with emerging countries on technology rather than on labor cost."

Insight 6: AM creates a cascading effect that converges in a better competitive advantage for the single firm as well at the district level.

\section{Conclusion}

The case studies showed that AM can improve the competitiveness of SMEs (Insight 6). In fact, innovation allowed by AM can create a better value offered to customers (Insight 3), an increase in the willingness to pay (Insight 4), and better access to new market segments (Insight 5), resulting in an improvement in the revenue stream (Insight 4). These effects appear to be generalized and extended to firms in other sectors due to the primary effects of AM, among which the authors highlight: the improvement of product innovation (Insight 3), creating more value for customers, improving time to market, and personalization and creative possibilities (Martinez - Ros, 1999; Hall et al., 2009; Reichstein and Salter, 2006; Love and Roper, 2015). Likewise, the effects on costs appear more related to the sector and manufacturing processes. The AM process determines the common effects of process innovations (Insight 1) identified by the literature: it promotes product innovation and improves business competitiveness while acting more on revenues than on cost reduction (Becheikh et al., 2006).

The authors can, therefore, say that AM is a viable development path for the manufacturing sector. In particular, this technology has proven its effectiveness in the areas where it is required for the production of complex objects by affecting production costs, especially in the possibility to turn a small-scale production into a large-scale one (Mellor and Zhang, 2014). This fact, along with a low adoption cost, shows that SMEs are becoming more competitive on two sides. The first is the ability to have access to new markets by expanding the range of products offered. The second, and perhaps most important, concerns the difficulty to produce imitation thanks to highly technical processes and design knowledge.

Hence, AM seems to favor innovation and growth processes within manufacturing firms, since the introduction of this innovation is a primary competitive factor that becomes a critical role in customer service operations as Beta's owner have remarked in paragraph 4.6. In this context, the introduction of AM can allow SMEs in countries with mature economies to remain competitive. This is possible due to the direction in which economic activity has gradually moved in the direction of service industries.

The last fundamental consideration is that AM does not create a loss of craftsmanship, but rather increases the creative potential of entrepreneurs and designers. Although less manual craftsmanship is required in this production stage, it is important to highlight that in general the traditional approach and creativity are enhanced by a new technological tool. 
Regarding practical implications, the study aims to increase the awareness of entrepreneurs and managers against the effects of the introduction of AM on firm performance and to shed light on this growing phenomenon, especially regarding the effects on costs. In fact, manager and entrepreneurs should have to pay attention to this fundamental evidence, especially if they would be competitive on the costs side.

The authors also aim to stimulate the attention of decision makers towards process innovations and its effect on firm competitiveness. AM is helping the Arezzo district to survive, granting a competitive advantage to their SMEs in the next years.

In conclusion, it should be noted that this work has limitations related to sample size and analysis of a single industry. As a result, the possible developments for future research may consist of the study of the effects of AM on the competitiveness of companies in different industries. Another limitation of this studies consists that the authors have used a qualitative technique to report some quantitative results. In particular, regarding productivity and revenues, it is only possible to report on perceptions of value created by managers and owners rather than a direct quantitative causative relationship.

Finally, it should also be noted that in literature analysis there are few contributions focused on AM due to the novelty of the phenomenon in question.

\section{References}

Acs, Z.J. and Audretsch, D.B. (1990). Innovation and Small Firms. MIT Press, Cambridge, Massachusetts.

Anderson, A.R., Drakopolou Dodd, S. and Jack, S. (2010). Network practices and entrepreneurial growth. Scandinavian Journal of Management, 26(2): 121-133.

Becheikh, N, Landry, R. and Amara, N. (2006). Lessons from innovation empirical studies in the manufacturing sector: A systematic review of the literature from 1993-2003. Technovation, 26(5): 644-664.

Berg, B. L. (2012). Qualitative research methods for the social sciences. Pearson, Boston, MA.

Campbell, T., Williams, C., Ivanova, O. and Garrett, B. (2011). Could 3D printing change the world. Technologies, Potential, and Implications of Additive Manufacturing. Atlantic Council, Washington, DC.

Caputo, A., Marzi, G. and Pellegrini, M. M. (2016). The internet of things in manufacturing innovation processes: development and application of a conceptual framework. Business Process Management Journal, 22(2): 383-402.

Chang, Y. Y., Hughes, M. and Hotho, S. (2011). Internal and external antecedents of SMEs' innovation ambidexterity outcomes. Management Decision, 4910: 1658-1676.

Columbus, L. (2015). 2015 Roundup of 3D Printing Market Forecasts and Estimates. Forbes. Available at: http://www.forbes.com/sites/louiscolumbus/2015/03/31/2015-roundup-of-3dprinting-market-forecasts-and-estimates. Retrieved: September, $24^{\text {th }} 2016$.

Damanpour, F. (1991). Organizational Innovation: A Meta-Analysis of Effects of Determinants and Moderators. Academy of Management Journal, 34(3): 555-590.

Dewar, R.D. and Dutton, J.E. (1986). The adoption of radical and incremental innovations: An empirical analysis. Management Science, 32(11): 1422-1433.

Dimitrov, D., Schreve, K. and De Beer, N. (2006). Advances in three dimensional printing-state of the art and future perspectives. Journal for New Generation Sciences, 21(1): 21-49.

Eisenhardt, K.M. (1989). Building Theories from Case Study Research. Academy of Management Review, 14(4): 532-550.

Ettlie, J.E., Bridges, W.P. and O'Keefe, R.D. (1984). Organization strategy and structural differences for radical versus incremental innovation. Management Science, 30(6): 682-695. 
Evangelista R., Perani G., Rapiti F. and Archibugi D. (1997). Nature and impact of innovation in manufacturing industry: some evidence from the Italian innovation survey. Research Policy, 26(4): 521-536.

Finch, J., (2002). The role of grounded theory in developing economic theory. Journal of Economic Methodology, 9(2): 213-234.

Freel, M.S. (2000). External linkages and product innovation in small manufacturing firms. Entrepreneurship \& Regional Development, 12(3): 245-266.

Freel, M.S. (2005). Patterns of innovation and skills in small firms. Technovation, 25(2): 123-134.

Garcia, R. and Calantone, R. (2002). A critical look at technological innovation typology and innovativeness terminology: a literature review. Journal of Product Innovation Management, 19(2): 110-132.

Golovko, E. and Valentini, G. (2011). Exploring the complementarity between innovation and export for SMEs' growth. Journal of international business Studies, 42(3): 362-380.

Hall, B.H., Lotti, F. and Mairesse, J. (2009). Innovation and productivity in SMEs: empirical evidence for Italy. Small Business Economics, 33(1): 13-33.

Hoffman, K., Parejo, M., Bessant, J. and Perren, L. (1998). Small firms, R\&D, technology and innovation in the UK: a literature review. Technovation, 18(1): 39-55.

Hull, F. M., Hage, J. and Azumi, K. (1985). R\&D management strategies: American versus Japan. IEEE Transactions on Engineering Management, 32(2): 78-83.

Hurmelinna-Laukkanen, P., Sainio L.M. and Jauhiainen T. (2008). Appropriability regime for radical and incremental innovations. $R \& D$ Management, 38(3): 278-289.

Jones, O. and Tilley, F. (2003). Competitive Advantage in SMEs: organizing for Innovation and Change. Wiley, Chichester.

Kannattukunnel, R. S. (2016). Global Patents on 3D Printing: Revelations Based on Vector Autoregression Analysis for Three Decades. International Journal of Innovation and Technology Management, 1750004.

Katila, R. (2002). New product search over time: Past ideas in their prime?. Academy of Management Journal, 45(5): 995-1010.

Katila, R. and Ahuja, G. (2002). Something old, something new: A longitudinal study of search behavior and new product introduction. Academy of Management Journal, 45(6): 1183-1194.

Katstra, W.E., Palazzolo, R. D., Rowe, C.W., Giritlioglu, B., Teung, P. and Cima, M.J. (2000). Oral dosage forms fabricated by Three Dimensional Printing ${ }^{\text {TM }}$. Journal of Controlled Release, 66(1): $1-9$.

Kimberly, J.R. and Evanisko, M.J. (1981). Organizational innovation: The influence of individual, organizational, and contextual factors on hospital adoption of technological and administrative innovations. Academy of Management Journal, 24(3): 689-713.

Kleinknecht, A. and Reijnen, J.O.N. (1992). Why do firms co-operate on R\&D? An empirical study. Research Policy 21, 347-360.

Knight, G. A. and Cavusgil, S.T. (2004). Innovation, organizational capabilities, and the born-global firm. Journal of International Business Studies, 352: 124-141.

Knudsen, T. and Levinthal, D.A. (2007). Two faces of search: Alternative generation and alternative evaluation. Organization Science, 18(1): 39-54.

Lagacé, D. and Bourgault, M. (2003). Linking manufacturing improvement programs to the competitive priorities of Canadian SMEs. Technovation, 23(8): 705-715.

Laursen, K. and Salter, A.J. (2004). Searching high and low: what type of firms use universities as a source of innovation?. Research Policy, 33 8. 1201-1215. 
Laursen, K. and Salter, A. (2006). Open for Innovation: The Role of Openness in Explaining Innovation Performance among UK Manufacturing Firms. Strategic Management Journal, 23(2): 131-150.

Lee, M., Dunn J. C. and Wu, B.M. (2005). Scaffold fabrication by indirect three-dimensional printing. Biomaterials, 26(20): 4281-4289.

Lee, S., Park, G., Yoon, B. and Park, J. (2010). Open innovation in SMEs-An intermediated network model. Research Policy, 392: 290-300.

Lefebvre, L.A., Lefebvre, E. and Colin, D. (1991). Process innovation, productivity, and competitiveness in smaller manufacturing firms. Canadian Journal of Administrative Sciences, 8(1): 19-28.

Li, Q., Maggitti, P.G., Smith, K.G., Tesluk, P.E. and Katila, R. (2013). Top Management Attention to Innovation: The Role of Search Selection and Intensity in new Products Introduction. Academy of Management Journal, 56(3): 893-916.

Linder, J.C., Jarvenpaa, S. and Davenport, T.H. (2003). Toward an innovation sourcing strategy. MIT Sloan Management Review, 44(4): 43-50.

Love, J. H. and Roper, S. (2015). SME innovation, exporting and growth: A review of existing evidence". International Small Business Journal, 33(1): 28-48.

Maggitti, P.G., Smith, K.G. and Katila, R. (2013). The complex search process of invention, Research Policy, 42(1): 90-100.

Marsili, O. and Salter, A.J. (2005). Is innovation democratic? Skewed distributions and the returns to innovation in Dutch manufacturing. Economics of New Technology and Innovation, 14(1-2): 83102.

Martinez-Ros, E. (1999). Explaining the decisions to carry out product and process innovations: the Spanish case. Journal of High Technology Management Research, 10(2): 223-242.

Marzi, G., Dabić, M., Daim, T., \& Garces, E. (2017). Product and process innovation in manufacturing firms: a 30-year bibliometric analysis. Scientometrics, Forthcoming.

Mayan, M. J. (2009). Essentials of qualitative inquiry. Leaf Coast Press, Walnut Creek, CA.

Mellor, S., Hao, L. and Zhang, D. (2014). Additive manufacturing: A framework for implementation. International Journal of Production Economics, 149: 194-201.

Miller, L. and Miller, R. (2012). Classifying innovation. International Journal of Innovation and Technology Management, 9(01), 1250004.

Narula, R. (2004). R\&D collaboration by SMEs: new opportunities and limitations in the face of globalization. Technovation, 25: 153-161.

Nord, W. R. and Tucker, S. (1987). Implementing routine and radical innovation. Lexington Books: Lexington, MA.

Parida, V., Westerberg, M. and Frishammar, J. (2012). Inbound open innovation activities in high-tech SMEs: the impact on innovation performance. Journal of Small Business Management, 50(2), 283-309.

Pavitt, K.L.R. (1998). Technologies, products and organization in the innovating firm: what Adam Smith Tells us and Joseph Schumpeter doesn't. Industrial and Corporate Change, 7(3): 433-452.

Petrick, I. J. and Simpson, T.W. (2013). 3D printing disrupts manufacturing. Research Technology Management, 566: 12.

Pratt, M.G. (2009). For the lack of a boilerplate: tips on writing up and reviewing qualitative research. Academy of Management Journal, 525: 856-62.

Raymond, L. and St-Pierre, J. (2010). R\&D as a determinant of innovation in manufacturing SMEs: An attempt at empirical clarification. Technovation, 30(1): 48-56.

Reeves, P., Tuck, C. and Hague, R. (2011). Additive manufacturing for mass customization. In Mass Customization pp. 275-289. Springer London.

Reichstein, T. and Salter, A. (2006). Investigating the sources of process innovation among UK manufacturing firms. Industrial and Corporate Change, 15(4): 653-682. 
Richards L. and Morse J.M. (2007). Readme first for a users' guide to qualitative methods. Sage, Thousand Oaks, CA.

Ruzzier, M., Hisrich, R. D. and Antoncic, B. (2006). SME internationalization research: past, present, and future. Journal of Small Business and Enterprise Development, 134: 476-497.

Sapienza, H. J., Autio, E., George, G. and Zahra, S. A. (2006). A capabilities perspective on the effects of early internationalization on firm survival and growth. Academy of Management Review, 314: 914-933.

Sealy, W. (2011). Additive manufacturing as a disruptive technology: how to avoid the pitfall. American Journal of Engineering and Technology Research, 1110.

Sirilli, G. and Evangelista, R. (1998). Technological innovation in services and manufacturing: results from Italian surveys. Research policy, 27(9): 881-899.

Siqueira, A.C.O. and Cosh, A. D. (2008). Effects of product innovation and organizational capabilities on competitive advantage: evidence from UK small and medium manufacturing enterprises. International Journal of Innovation Management, 12(02), 113-137.

Smith, W.K. and Tushman, M.L. (2005). Managing strategic contradictions: A top management model for man-aging innovation streams. Organization Science, 16(5): 522-536.

Sorli, M. and Stokic, D. (2011). Future trends in product/process innovation. International Journal of Innovation and Technology Management, 8(04), 577-599.

Spiggle, S. (1994). Analysis and interpretation of qualitative data in consumer research. Journal of Consumer Research, 21 December: 491-503.

Taifi, N., Lazoi, M., Corallo, A., Passiante, G. and Lazoi, M. (2012). Integrated systems and outsourcing: Process innovation in aerospace product design. International Journal of Innovation and Technology Management, 9(03), 1250019.

Tajeddini, K. (2016). Financial Orientation, Product Innovation and Firm Performance: An Empirical Study in the Japanese SMEs. International Journal of Innovation and Technology Management, 1640005.

Terziovski, M. (2010). Innovation practice and its performance implications in small and medium enterprises SMEs in the manufacturing sector: a resource-based view. Strategic Management Journal, 31(8): 892-902.

Thompson, C.J. (1997). Interpreting Consumers: A Hermeneutical Framework for Deriving Marketing Insights from the Texts of Consumers' Consumption Stories. Journal of Marketing Research, 344. 438-455.

Tushman, M.L.A. and Anderson, P. (1986). Technological discontinuities and organizational environments. Administrative Science Quarterly, 31(3): 439-465.

Utterback, J.M. and Abernathy, W.J. (1975). A dynamic model of process and product innovation. Omega, 3(6): 639-656.

Uzzi, B. (1997). Social structure and competition in interfirm networks: The paradox of embeddedness. Administrative Science Quarterly, 42(1): 35-67.

Witt, U. (2009). Propositions about novelty. Journal of Economic Behavior and Organization, 70(12): 311-320.

Woodside, G. and Wilson, E.J. (2003). Case study research methods for theory building. Journal of Business \& Industrial Marketing, 187: 493-508.

Yin, R.K. (2004). Case Study Research, Sage, Beverly Hills, CA.

Zeng, S. X., Xie, X. M. and Tam, C. M. (2010). Relationship between cooperation networks and innovation performance of SMEs. Technovation, 30(3), 181-194. 
Zollo, L., Marzi, G., Boccardi, A. and Surchi, M. (2015). How to match technological and social innovation: insights from the biomedical 3D printing industry. International Journal of Transitions and Innovation Systems, 4(1-2): 80-95.

\section{Web Sites}

http://dati.istat.it/

\section{Appendix}

\begin{tabular}{|c|c|c|}
\hline & Questions & Area of Investigation \\
\hline 1 & $\begin{array}{l}\text { What reasons prompted you to use Additive Manufacturing (or 3D } \\
\text { Printing)? }\end{array}$ & Innovation \\
\hline 2 & Was it a particularly onerous or a sustainable investment? & Effect on Cost \\
\hline 3 & $\begin{array}{l}\text { Has Additive Manufacturing (or 3D Printing) made a significant } \\
\text { innovation in the production process? }\end{array}$ & Process Innovation \\
\hline 4 & $\begin{array}{l}\text { What effect has Additive Manufacturing (or 3D Printing) made in } \\
\text { the HRM? }\end{array}$ & Organizational Effects \\
\hline 5 & $\begin{array}{l}\text { Does Additive Manufacturing (or 3D Printing) produce any effects } \\
\text { on cost reduction? }\end{array}$ & Effect on Cost \\
\hline 6 & $\begin{array}{l}\text { Does Additive Manufacturing (or 3D Printing) produce any effects } \\
\text { on cost structure? }\end{array}$ & Effect on Cost \\
\hline 7 & $\begin{array}{l}\text { What have been the effects on the cost of designing and developing } \\
\text { new products? }\end{array}$ & $\begin{array}{l}\text { Effect on Cost/New Product } \\
\text { Development }\end{array}$ \\
\hline 8 & $\begin{array}{l}\text { Does Additive Manufacturing (or 3D Printing) stimulate product } \\
\text { innovation? }\end{array}$ & Product Innovation \\
\hline 9 & $\begin{array}{l}\text { Has Additive Manufacturing (or 3D Printing) allowed you to } \\
\text { improve your products in terms of quality or complexity? }\end{array}$ & Product Innovation \\
\hline 10 & $\begin{array}{l}\text { Compared to the past, what has changed in the value offered to } \\
\text { costumers? }\end{array}$ & Product Innovation/Value Offered \\
\hline 11 & $\begin{array}{l}\text { Does Additive Manufacturing (or 3D Printing) make it possible to } \\
\text { increase the willingness of customers to pay a higher price? }\end{array}$ & Value Offered/Willingness to Pay \\
\hline 12 & $\begin{array}{l}\text { Does Additive Manufacturing (or 3D Printing) have any effects on } \\
\text { items sold? }\end{array}$ & Revenues \\
\hline 13 & $\begin{array}{l}\text { In terms of value added, have you acted more on cost or value } \\
\text { offered to the customer? }\end{array}$ & Value Offered \\
\hline 14 & $\begin{array}{l}\text { Does Additive Manufacturing (or 3D Printing) have any effects on } \\
\text { competitiveness? } \\
\text { If yes, do you think that it is defensible in the long run? }\end{array}$ & Competitive Advantage \\
\hline 15 & $\begin{array}{l}\text { Do you think that Additive Manufacturing (or 3D Printing) is } \\
\text { needed to compete today? }\end{array}$ & Competitive Advantage \\
\hline
\end{tabular}

Table 5 - Detailed interview plot 